\title{
Analisis Penyusunan Pesan Persuasif dalam Program Tausiyah MQ FM Bandung
}

\author{
Khoiruddin Muchtar ${ }^{1 *}$ \\ ${ }^{1}$ UIN Sunan Gunung Djati Bandung \\ *Email : khoiruddin@uinsgd.ac.id
}

\begin{abstract}
ABSTRAK
Penelitian ini bertujuan mengetahui teknik penyusunan pesan secara persuasive dan informative dalam Siaran Tausiyah Motovasi Awal Pekan di Radio 102.7 MQ. FM. Penelitian ini menggunakan paradigm konstruktivis, pendekatan kualitatif, dengan metode analisis terhadap isi pesan dengan susunan pesan dan teknik komunikasi persuasif. Hasil penelitian menunjukan bahwa, dalam menyampaikan pesan perlu adanya aturan yang baik dengan pemilihan kata-kata dan pengaturan pesan didalam penyampaiannya, pesan yang tersusun dengan baik dapat memotivasi audiensnya menuju kepada tingkah laku atau sikap yang sesuai dengan pesan dakwah. Sehingga pesan yang tersusun dengan baik mempunyai dampak yang lebih efektif dari pada pesan yang tidak tersusun.
\end{abstract}

Kata Kunci : Pesan Persuasif, Program Tausiyah, MQ FM Bandung

\begin{abstract}
This study aims to determine the technique of compiling messages in a persuasive and informative manner in the Tausiyah Motovasi Early Week Broadcast on Radio 102.7 MQ. FM. This study uses a constructivist paradigm, a qualitative approach, with the method of analyzing the content of the message with the composition of the message and persuasive communication techniques. The results of the study indicate that, in conveying messages, there needs to be good rules with the choice of words and message settings in the delivery, well-structured messages can motivate the audience towards behavior or attitudes that are in accordance with the message of da'wah. So that a well-structured message has a more effective impact than an unstructured message
\end{abstract}

Keywords : Persuasive Message, Tausiyah Program, MQ FM Bandung 


\section{PENDAHULUAN}

Dalam Al-Qur'an dakwah menduduki tempat dan posisi utama dalam menentukan keindahan dan kesesuaian Islam baik dalam sejarah maupun praktiknya, sangat ditentukan oleh kegiatan dakwah yang dilakukan oleh umatnya. Keberhasilan dakwah juga sangat dipengaruhi oleh bagaimana pesan dakwah itu disampaikan, sehingga media dakwah yang digunakan sebagai pesan obyek dakwah, komunikan dan pengaruh dari pesan yang disampaikan. Adanya pesan yang tepat, pesan yang baik dan menggunakan media yang benar dapat diharapkan komunikan akan terpengaruh oleh pesan yang disampaikan. Disamping itu penguasaan materi dakwah oleh narasumber yang menyampaikan pesan dakwah dan komunikasi dengan menggunakan media dakwah, dia harus mempersiapkan diri dengan membentuk karakter dalam dirinya sebagai pengemban dakwah yaitu dengan menyelaraskan antara ucapan dan perbuatannya, sehingga melekatkan sifat yang senantiasa menjadi akhlak dan prilaku sehari-hari baik saat ia menyampaikan dakwah maupun saat ia melaksanakan tugas-tugas kehidupan lainnya (Departmen Agama RI, 2002: 551).

Agar pesan bisa disampaikan dengan baik, maka narasumber dalam menyampaikan pesan dakwah harus mengetahui media yang tepat, apakah melalui media radio, televisi, atau majalah, untuk melakukan dakwahnya, karena tiap-tiap media mempunyai kelebihan dan kekurangan tersendiri, tergantung bagaimana narasumber dalam melaksanakan dakwahnya agar terlaksana. Diantara sekian banyak media komunikasi yang digunakan dalam proses dakwah, ada satu media yang sangat dekat dimasyarakat, yaitu radio, media radio banyak mendapat perhatian karena disamping ekonomis dan praktis yaitu mudah cara mendapatkannya, murah harganya, juga siarannya dapat didengar oleh berbagai lapisan masyarakat. Sebagai salah satu media massa elektronik yang keberadaannya sangat berpengaruh di masyarakat, radio diharapkan mampu memberikan informasi, hiburan sekaligus pendidikan massal kepada masyarakat (Frank, 1992: 87).

Radio merupakan media komunikasi yang dipergunakan dalam mengirim warta jarak jauh yang dapat ditangkap oleh sekelompok orang yang mendengarnya melalui pemancar radio yang diinginkan. Dalam kegiatan dakwah, radio sangat penting dalam penyampaian materi dakwah dalam bentuk pidato dan ceramah atau kuliah. Pesawat radio dapat menjangkau mad'u (objek dakwah) dalam jarak jauh dan meluas.

Kelebihan dakwah melalui radio terletak pada efektifitas dan efisiensi berdakwah. Hal ini tampak dari adanya bentuk yang sederhana tanpa harus bertemu antara $d a^{\prime} i$ (subjek dakwah) dan mad’u (objek dakwah) (Ghazali, 1997: 63). Atas dasar kelebihan yang ada pada radio, maka perlu sekali dimanfaatkan sebagai media dakwah seperti yang terlihat sekarang ini. Penggunaan radio sebagai media 
dakwah Islam dipandang cukup membawa hasil dan sampai pada sasarannya tanpa banyak mengalami hambatan.

Radio sebagai media dakwah memiliki beberapa keutamaan antara lain: 1) Program radio dipersiapkan oleh seorang ahli, sehingga bahan yang disampaikan benar-benar bermutu. 2) Radio merupakan bagian dari budaya masyarakat. 3) Harga dan biaya cukup murah sehingga masyarakat mayoritas memilih alat ini. 4) Mudah dijangkau oleh masyarakat, artinya audience atau pendengar cukup dirumah. 5) Radio mampu menyampaikan kebijaksanaan, informasi secara tepat dan akurat. 6) Pesawat radio mudah dibawa kemana-mana.

Setiap radio memiliki program siaran yang mampu memberikan informasi penting bagi masyarakat dan siaran yang disampaikan pun beragam ada informasi mengenai hiburan dan pendidikan serta mampu memberikan informasi yang bermanfaat bagi para pendengarnya. Oleh karena itu sebagai salah satu media massa, peranan radio dalam siarannya sangat diharapkan oleh masyarakat untuk mengisi program siarannya dalam bidang keagamaan terutama tentang program siaran kajian agama Islam. Media radio yang digunakan sebagai media dakwah merupakan suatu bentuk pembaharuan siaran religius yang bersifat konvensional sehingga siarannya mampu bersaing dengan program siaran yang lain.

Radio 102,7 MQ FM salah satu radio di Bandung yang digagas dan di dirikan oleh K. H Abdullah Gymnastiar pada tanggal 3 Agustus 2001 yang beralamatkan di Jl. Gegerkalong Girang No. 32 Bandung. Radio MQ FM lahir ditengah masyarakat dengan sajian-sajian program acara yang menyejukkan hati dan penuh hikmah sebagai alternatif dari warna radio lain yang sudah ada. Dengan membawa nuansa berbeda layaknya sebuah oase di tengah kegersangan, kehadiran Radio MQ FM membawa identitas Islam damai, Islam Rahmatan Lil'alamin dan membangun profesionalisme muslim serta jiwa entrepreneurship. Untuk itu radio 102,7 MQ FM harus menjadi media perubahan bagi masyarakat dan bangsa ke arah yang lebih baik (Company Profil Radio 102,7 MQ FM Bandung).

Radio MQ FM hadir menemani aktifitas pendengar yang membutuhkan sentuhan rubaniyah untuk mengisi relung hati yang merindukan kedamaian, ketenangan, dan kebeningan melalui sajian program siaran yang berupa pencerahan dan kesejukan yang memberi manfaat, hikmah serta nilai-nilai akhlak yang mulia. Radio MQ FM mempunyai peran dalam mengembangkan dakwah Islam diseluruh Nusantara umumnya, dan wilayah Bandung khususnya, fenomena inilah yang kiranya menjadi munculnya siaran Tausiyah Motivasi Awal Pekan di Radio MQ FM, yang mencoba menyajikan dakwah dengan berbeda yaitu dengan tema dan materi yang mampu menghadirkan nuansa berbeda dalam berdakwah. Dalam siaran Tausiyah Motivasi Awal Pekan, dakwah yang disajikan lebih banyak menjelaskan materi dengan memotivasi para pendengarnya bagaimana menjalani kehidupan sesuai dengan tuntunan Allah SWT dan Rasul- Nya. 
Tausiyah Motivasi Awal Pekan merupakan salah satu program yang ada di Radio 102,7 MQ FM dengan durasi sebanyak 60 menit, dengan narasumber Ustadz Rahmad Muryodo, dengan tema yang disajikan tiap minggunya bisa dibilang relevan dengan keadaan sekarang dan dialog interaktif antara pendengar dirumah dengan ustadz mengenai masalah-masalah agama yang dihadapi dalam kehidupan sehari-hari. Oleh karena itu, siaran Tausiyah Motivasi Awal Pekan pada bulan November 2015 menarik untuk diteliti, karena ustadz dalam menyampaikan pesan kepada pemirsa mencoba menggunakan bahasa yang mudah dipahami, cara menganalisis masalah juga mudah dimengerti, dan masalah yang diangkat dalam siaran Tausiyah Motivasi Awal Pekan selalu menyesuaikan dengan perkembangan zaman. Adapun tujuan dari penelitian ini adalah untuk mengetahui susunan pesan dan teknik persuasif ustadz Rahmad Muryodo dalam siaran Tausiyah Motivasi Awal Pekan pada bulan November 2015 di Radio 102,7 MQ FM, acaranya setiap hari senin pukul 07.30 - 08.30 WIB dengan format acaranya yaitu dialog interaktif tentang kajian Islam dan motivasi.

Penelitian tentang Teknik Penyusunan Pesan dan Teknik Persuasif dalam Siaran Tausiyah Motivasi Awal Pekan di Radio 102,7 MQ FM akan menggunakan metode analisis terhadap isi pesan dengan susunan pesan dan teknik persuasif ustadz Rahmad Muryodo dalam rekaman siaran Tausiyah Motivasi Awal Pekan bulan November 2015, agar pengkajian dapat dilakukan secara efektif dan efesien, maka perlu disusun langkah-langkah penelitian

Obyek Penelitian, Obyek yang akan dikaji dalam penelitian ini adalah Teknik Penyusunan Pesan dan Teknik Persuasif dalam siaran Tausiyah Motivasi Awal Pekan pada bulan November 2015. Dalam menentukan obyek penelitian ini peneliti mengambil rekaman siaran Tausiyah Motivasi Awal Pekan pada bulan November 2015.

Subyek Penelitian, adapun yang menjadi subyek penelitian ini adalah programer dicertor, penyiar dan narasumber yang dianggap memiliki peranan penting dalam siaran Tausiyah Motivasi Awal Pekan. Sifat Penelitian, berdasarkan permasalahan yang diajukan dalam penelitian, yakni hasilnya lebih menekankan pada keterangan isi pesan yang disampaikan dalam hal ini adalah penggunaan susunan pesan dan teknik persuasif, oleh karena itu penelitian ini bersifat deskripsif analisis kualitatif, yaitu berusaha untuk melukiskan secara sistematis fakta atau karakteristik populasi tertentu atau bidang tertentu secara faktual dan cermat (Rahmat, 2004: 22). Dalam penelitian ini, penulis meneliti rekaman siaran Tausiyah Motivasi Awal Pekan pada bulan November 2015, namun dalam hal ini penelitian yang diteliti adalah penggunaan susunan pesan dan teknik persuasif ustadz Rahmad Muryodo dalam menyampaikan pesan dakwah melalui siaran Tausiyah Motivasi Awal Pekan di Radio 102,7 MQ FM Bandung.

Teknik Pengumpulan Data dilakukan dengan wawancara, observasi dan dokumentasi. Wawancara dalam penelitian dilakukan dengan interview, yang 
digunakan adalah interview berpedoman bebas terpimpin yaitu pewawancara menentukan sendiri urutan sistematika wawancara, bagaimana cara pertanyaan untuk disajikan, terserah pada pewawancara. Pelaksanaan wawancara guna menghimpun data yang akurat untuk keperluan pelaksanaan proses pemecahan masalah tertentu yang sesuai dengan data.

Metode ini digunakan untuk mewawancarai ustadz, penyiar siaran Tausiyah Motivasi Awal Pekan dan para staf Radio 102,7 MQ FM. Aspek yang diwawancarai meliputi data tentang gambaran mengenai siaran Tausiyah Motivasi Awal Pekan bulan November 2015.

Observasi dilakukan dengan cara mengamati obyek yang merupakan sumber utama data (Kountor, 2007: 184). Dengan penggunaan metode ini, diharapkan dapat diperoleh gambaran secara obyektif keadaan yang diteliti.

Dokumentasi, metode ini digunakan untuk mendapatkan data penunjang yang berhubungan dengan persoalan penelitian berupa rekaman, gambar, bendabenda peninggalan yang berkaitan dengan peristiwa (Suprayogo dan Tobroni, 2001: 164).

Analisis Data, setelah data terkumpul dengan lengkap, selanjutnya dibuat kategori untuk masing-masing kriteria permasalahan yang akan diteliti, pembuatan kategori ini dibuat agar mampu menganalisa susunan pesan dan teknik peruasif ustadz Rahmad Muryodo dalam siaran Tausiyah Motivasi Awal Pekan bulan November 2015 yang menjadi obyek penelitian.

Secara ringkas proses penelitian penggunaan susunan pesan dan teknik persuasif dalam siaran Tausiyah Motivasi Awal Pekan pada bulan November 2015 di Radio 102,7 MQ FM Bandung dapat penulis gambarkan sebagai berikut: Mendengarkan secara cermat terhadap isi rekaman siaran, mentransfer data dalam bentuk tulisan, menganalisa pesannya, diteliti bagaimana susunan pesan dan teknik persuasif, diklasifikasikan sesuai dengan permasalahan yang ada pada penelitian, kemudian dianalisis dan dikemas kedalam bentuk laporan yang sistematis dan siap disajikan untuk dibaca. Dalam mengklasifikasikan teori dalam penelitian ini, penulis klasifikasikan dengan dua klasifikasi yaitu penggunaan susunan pesan dan teknik persuasif dalam penyampaian pesan.

\section{HASIL DAN PEMBAHASAN}

Penyampain pesan yang tersusun dengan baik akan lebih efektif daripada penyajian pesan yang tidak tersusun. Susunan pesan pada tataran persuasif memiliki tujuan untuk mengubah persepsi, tingkah laku, dan pendapat khalayak, sehingga dalam penyusunan pesan diperlukan sebuah proposisi yaitu apa yang dikehendaki sumber terhadap penerima sebagai hasil pesan yang disampaikannya dengan harapan apa yang dibuat diinginkan adanya perubahan. Sementara itu, 
penyusunan pesan yang bersifat informatif lebih ditunjukan kepada penambahan wawasan dan kesadaran khalayak (Cangara, 2007: 116).

Para ahli komunikasi mengemukakan bahwa penyajian pesan yang tersusun lebih efektif dari pada penyajian pesan yang tidak tersusun dengan kata lain, bahwa tidak ada satu penelitian pun yang membuktikan bahwa pesan yang tidak tersusun dengan baik mempunyai pengaruh yang lebih efektif dari pada pesan yang tersusun dengan baik. (Rahmat, 2000: 295)

Setiap orang mempunyai kemampuan berbicara baik secara verbal maupun non verbal, tetapi tidak semua orang mempunyai kemampuan berbicara baik, jelas, singkat dan tepat mengenai sasaran, karena seorang pembicara menyampaikan buah pikiran melalui proses berpikir agar pesan itu tersusun dengan baik agar bisa didengar guna memperoleh akibat yang sesuai dengan tujuan yang akan diutarakannya. Pengorganisasian pesan dalam komunikasi merupakan faktor yang penting dalam menentukan keberhasilan kegiatan komunikasi yang berusaha mempengaruhi atau meyakinkan khalayak sasaran.

Teknik peyusunan pesan merupakan cara orang dalam menyampaikan buah pikiran dan perasaannya secara rinci untuk bisa menggunakan pikirannya secara logis agar mampu menguraikan secara jelas, terang dan tegas. Jadi penggunaan teknik penyusunan pesan bagi para da’i sangat berguna untuk membuktikan maksud dan pembicaraan atau menampakkan pembuktian, demikian juga dalam menyampaikan pesan dengan persuasif agar bisa mempengaruhi orang lain, dan mereka dapat mengalihkan pikirannya dari pikiran-pikiran yang mungkar kepada pikiran yang sesuai dengan tuntutan Allah, termasuk di dalamnya dapat mempengaruhi keyakinan, perbuatan, dan perilaku. Sedangkan penyampaian pesan secara informatif untuk menambah wawasan dan kesadaran khalayak.

Pesan yang diorganisasikan dengan baik itu mudah dimengerti dari pada pesan yang tidak tersusun dengan baik, sebagian lagi menunjukkan bahwa pesan yang tersusun dengan baik memudahkan pesan itu dapat diingat oleh pendengar. Pesan yang tersusun dan tertib akan menciptakan suasana yang membangkitkan minat, memperlihatkan pembagian pesan yang jelas sehingga memudahkan pengertian, mempertegas gagasan pokok dan menunjukkan perkembangan pokok pikiran secara logis karenanya sudah sejak lama para ahli komunikasi menunjukkan cara-cara penyusunan pesan yang akan disampaikan.

\section{Penyusunan Pesan Bersifat Persuasif}

Istilah persuasif (persuation) bersumber pada perkataan latin yang berarti membujuk, mengajak, atau merayu (Effendi, 2004: 21), yaitu bagaimana komunikasi yang telah direncanakan dapat mempengaruhi orang lain dengan mengubah sikap mereka, dalam suatu komunikasi.

Penyusunan pesan bersifat persuasif yang dimaksud disini adalah suatu teknik komunikasi dengan jalan merangsang dan membangkitkan emosi dari 
audiens dengan tujuan agar audiens melakukan tindakan sesuai dengan yang diharapkan (Cangara, 2007: 116). dalam hal ini dikarenakan tujuan dari dakwah ialah supaya audiens meyakini dan mengikuti pesan yang telah disampaikan.

Agar komunikasi persuasif mencapai tujuan dan sasaran maka perlu dilakukan perencanaan yang matang, bagi komunikator perlu mengadakan pengelolaan pesan yaitu pesan harus ditata sesuai kondisi komunikan dan bisa menyentuh aspek psikologis dengan proses persuasif. Kegiatan persuasif dapat berhasil bila menyentuh aspek motif yang menggerakan prilaku manusia, atau dengan kata lain mengimbau dengan menyentuh aspek psikologis yang mendasar bagi manusia. Ajakan lewat sentuhan persuasif dalam menyampaikan pesan dapat kita ketahui dengan beberapa hal yaitu;

Fear Appeal. Metode penyusunan pesan dengan menimbulkan rasa ketakutan kepada khalayak. Sehingga khalayak kurang senang menerima pesan yang disertai ancaman menakutkan, meresahkan dengan cara menggambarkan konsekuensi yang buruk yang akan terjadi, sehingga membangkitkan rasa takut. Sebab mereka tidak memiliki kebebasan untuk menentukan sikap dan mengemukakan pendapatnya.

Emotional Appeal. Penyusunan pesan dengan berusaha menggugah khalayak dengan menggunakan pernyataan-pernyataan atau bahasa yang menyentuh emosi komunikan dengan mempermainkan bahasa dan ekspresi bahasa seperti dengan menggunakan kata-kata.

Reward Appeal. Penyusunan pesan dengan menawarkan janji-janji kepada khalayak dengan menggunakan rujukan yang menjanjikan komunikan, yaitu sesuatu yang mereka perlukan atau yang mereka inginkan dengan cara mengimingimingi hal yang menguntungkan atau yang menjanjikan harapan.

Motivational Appeal. Cara penyusunan pesan yang dibuat bukan karena janji-janji, tetapi disusun untuk menumbuhkan internal psikologis khalayak yang menyentuh kondisi interen dalam diri manusia, seperti motif biologis sehingga mereka dapat mengikuti pesan-pesan itu.

Humorious Appeal, yaitu teknik penyusunan pesan yang disertai humor sehingga dalam penerimaan pesan pendengar tidak jenuh, pesan yang disertai humor mudah diterima, enak dan menyegarkan. Hanya saja dalam penyampaian pesan yang disertai humor diusahakan jangan sampai terjadi menyentuh aspek kejiwaan.

\section{Penyusunan Pesan Bersifat Informatif.}

Model penyusunan pesan yang bersifat informatif lebih banyak ditujukan pada perluasan wawasan dan kesadaran khalayak. Prosesnya lebih banyak bersifat difusi, sederhana, jelas dan tidak banyak menggunakan jargon yang kurang populer dikalangan masyarakat. 
Ada empat macam penyusunan pesan bersifat informatif; 1) Space Order. Penyusunan pesan yang melihat kondisi tempat atau ruang, seperti; internasional, nasional dan daerah, 2) Time Order, penyusunan pesan berdasarkan waktu atau periode yang disusun secara kronologis.

3) Deductive Order. Penyusunan pesan dimulai dari hal-hal yang bersifat umum kepada hal-hal yang bersifat khusus. 4) Inductive Order Kebalikan dari Deduktive Order, yaitu penyusunan pesan yang dimulai dari hal-hal khusus kepada yang bersifat umum. (Changara, 2011: 265)

Model penyusunan pesan informatif biasanya banyak dilakukan dalam penulisan berita dan artikel oleh para wartawan dengan memakai model piramida terbalik. Dalam penulisan berita model straight news penyampaian pesan bergerak dari yang sangat penting kepada yang kurang penting dengan menjawab $5 \mathrm{~W}+1$ $\mathrm{H}$.

\section{Radio Sebagai Media Dakwah}

Dakwah berasal dari bahasa arab yang berarti: doa, ajakan, seruan, undangan, panggilan (Munawir, 1987: 407), yakni menyampaikan seruan Islam, mengajak dan memanggil umat manusia agar menerima dan mempercayai keyakinan dan pandangan hidup Islam (Romli, 2003: 6). Banyak sekali pengertian dakwah yang dikemukakan oleh para ahli dakwah, tapi pada prinsipnya dapat disimpulkan bahwa dakwah adalah aktivitas mengubah situasi dan kondisi yang sesuai dengan kehidupan Islam. Dengan demikian yang diinginkan oleh dakwah adalah terjadinya perubahan ke arah kehidupan yang lebih Islami.

Jadi yang dimaksud berdakwah dengan menggunakan media radio adalah keterampilan dalam menyampaikan pesan ajaran Islam secara lisan guna memberikan pemahaman yang benar kepada kaum muslimin agar mereka dapat dengan mudah menerima seruan dakwah Islam yang karenanya pemahaman dan perilakunya dapat berubah dengan menghadirkan media radio sebagai sarana untuk menyampaikan dakwah di masyarakat. Peroses pelaksanaan dakwah sebagai salah satu cara dalam menyiarkan agama Islam akan dapat terealisasikan secara efektif apabila strategi yang digunakan dalam berdakwah juga aplikatif artinya sesuai dengan pola perkembangan dan kehidupan masyarakat sesuai dengan zamannya.

Dalam mewujudkan tujuan dakwah diperlukan sebuah konsep dakwah yang bagus yang mampu mendukung pencapaian tersebut. Setidaknya menentukan unsur-unsur dakwah itu sendiri sebagai konsep dasar pelaksanaan dakwah. Persatuan Radio Siaran Swasta Nasional Indonesia (PRSSNI) telah menetapkan program keagamaan, yaitu:

Program keagamaan harus disajikan oleh perorangan atau organisasi yang bertanggung jawab. Program keagamaan harus disajikan dengan tanggung jawab, tanpa prasangka, dan tidak mempertentangkan keyakinan antar umat beragama. 
Stasiun radio tidak boleh menyiarkan acara keagamaan yang secara ritual atau peribadatannya tidak diterima oleh umum.

Program keagamaan tidak boleh menganjurkan perpindahan agama. Pelaksanaan dakwah melalui radio tidaklah mudah, karena disamping diperlukan seorang yang ahli juga perlu adanya persiapan yang matang tentang bahan-bahan yang akan disampaikan, dimana penyuguhan dakwah ini lebih menarik sehingga para pendengar akan merasakan kehilangan manakala siaran dakwah tidak terdengar lagi (Mimbar Ulama, 1978: 65).

Adapun bentuk siaran agama Islam yang biasa dipakai oleh pihak radio antara lain: Bentuk acara yang bersifat dialogis yaitu seorang da'i menyampaikan ke pendengar melalui radio, dan pendengar juga bisa ikut terlibat langsung dalam acara yang sedang berlangsung dengan bertanya kepada da'i, yang sering dilakukan adalah dengan menelpon dan SMS langsung. Bentuk acara yang bersifat monologis biasanya hanya memutar kaset yang sudah direkam.

\section{KESIMPULAN}

Penelitian mengenai susunan pesan pada penggunaan organisasi pesan yang digunakan narasumber siaran Tausiyah Motivasi Awal Pekan bulan November 2015 dalam menyampaikan pesan dakwahnya terdapat empat organisasi yang digunakan dalam organisasi pesan yaitu deduktif, induktif, logis, kronologis dan topical. Organisasi pesan itu digunakan sebagai penjelasan materi dalam menyampaikan pesan dakwah agar sampai kepada pendengar siaran Tausiyah Motivasi Awal Pekan, karena pesan yang sistematis dan tersusun baik akan mudah dimengerti untuk memahami isi materi yang disampaikan. Penggunaan topical lebih banyak digunakan karena narasumber mengemukakan penjelasan materi sesuai dengan tema pokok penjelasan, kemudian diperjelas isi materi dengan penggunaan deduktif dan induktif, sementara itu sebagai kombinasi dalam siaran Tausiyah Motivasi Awal Pekan logis dan kronoligis juga digunakan oleh narasumber, karena pesan yang sistematis dan tersusun baik akan mudah dimengerti untuk memahami isi materi yang disampaikan. Dari teknik penyampaian pesan yang mencakup dialog interaktif dapat meningkatkan tingkat kejelasan pada komunikan baik di studio maupun pendengar di rumah sebagai tingkat efektivitas penyampaian pesan dakwah melalui siaran Tausiyah Motivasi Awal Pekan dengan meningkat baik pada level kognisi dengan tingkat kejelasan yang lebih tinggi maupun pada level afeksi.

Penelitian mengenai penggunaan teknik persuasif oleh narasumber dalam siaran Tausiyah Motivasi Awal Pekan bulan November 2015, menggunakan beberapa teknik persuasif dalam penyampaian pesan yaitu fear appeal, emotional appeal, reward appeal, motivasional appeal, humorious appeal. Semua teknik penyampaian pesan telah digunakan dalam siaran Tausiyah Motivasi Awal Pekan 
Khoiruddin Muchtar

oleh narasumber hal ini dinilai cukup positif karena dalam dialog interaktif ratarata menelpon dan yang megirim sms adalah orang-orang yang ingin mendapatkan penjelasan dan keterangan agama secara rasional dan ilmiah menurut Alquran dan Hadist.

\section{DAFTAR PUSTAKA}

Cangara, H. (2007). Pengantar Ilmu Komunikasi, Jakarta: PT Raja Grafindo Persada

Cangara, H. (2011). Komunikasi Politik Konsep, Teori dan Strategi, Jakarta: Raja Grafindo Persada.

Company Profil Radio 102,7 MQ FM Bandung

Departemen Agama RI. (2002). Alquran Tajwid dan Terjemahannya. Bandung: PT Syaamil Cipta Media

Effendi, O. U. (2004). Dinamika Komunikasi, Bandung; Remaja Rosdakaraya Frank, J. (1992). Public Relations, Jakarta: Erlangga

Ghazali, B. (1997). Dakwah Komunikatif. Jakarta: Pedoman Ilmu Jaya

Kountor, R. (2007). Metode Penelitian; Untuk Penulisan Skripsi dan Tesis, Jakarta: Buana Printing.

Mimbar Ulama. (1978). Radio Sebagai Dakwah

Munawir, A. W. (1987). Kamus Al - Munawir Arab - Indonesia. Surabaya: Pustaka Progresif, 1987

Rahmat, J. (2000). Psikologi Komunikasi, Bandung, Remaja Rosda Karya

Rahmat, J. (2004). Metodologi Penelitian Komunikasi. Bandung: Rosdakarya.

Romli, A. S.(2003). Jurnalistik Dakwah, Bandung: Remaja Rosda Karya

Suprayogo. I, \& Tobroni. (2001). Metodologi Penelitian Sosial-Agama, Bandung: Remaja Rosda Karya 